\title{
PERLINDUNGAN HUKUM PELAKSANA IMUNISASI DALAM KEJADIAN IKUTAN PASCA IMUNISASI DI KABUPATEN SUKABUMI
}

\author{
Ahmad Juanda \\ Pegawai Dinas Kesehatan Kabupaten Sukabumi \\ e-mail: ahmadjuanda@gmail.com
}

\begin{abstract}
Abstrak-Imunisasi merupakan upaya preventif yang terbukti dapat menurunkan kesakitan, kecacatan dan kematian. Maka pemerintah mewajibkan pada masyarakat untuk mendapatkan imunisasi seperti yang dalam Permenkes nomor 42 tahun 2013 tentang Penyelenggaraan Imunisasi. Segala aturan dan tatalaksana imunisasi sudah dibuat pemerintah tentang hak dan kewajiban pemerintah dalam menyelenggarakan imunisasi. Walaupun demikian sudah diatur sebaik mungkin tetapi permasalahan selalu saja ada bila terjadi Kejadian Ikutan Paska Imunisasi (KIPI) yang membuat para Pelaksana Imunisasi dalam melaksanakan tugasnya. Kewajiban dalam pelaksanaan imunisasi ini tentu saja tidak dapat dihindari oleh Pelaksana Imunisasi walaupun selalu dibayangi kekhawatiran akan resiko KIPI. Oleh sebab itu penelitian ini bertujuan untuk mengkaji tentang perlindungan dan kebijakan hukum bagi Pelaksana Imunisasi dalam menjalankan tugasnya berdasarkan Permenkes Nomor 42 Tahun 2013 tentang Penyelenggaraan Imunisasi di indonesia. Hasil penelitian ini menunjukkan bahwa perangkat hukum yang disiapkan dalam penyelenggaraan imunisasi sudah cukup, tetapi kurangnya pemahaman hukum sering menimbulkan kekhawatiran akan terjadi KIPI, karena itu dalam pelaksanaan imunisasi hendaknya para pelaksana memahami resiko kesalahan dan kelalaian kerja, dan hal tersebut memerlukan adanya sosialisasi yang dilakukan oleh pemerintah tentang peraturan-peraturan yang berkaitan dengan penyelenggaraan imunisasi di Indonesia.
\end{abstract}

\section{Kata Kunci: Perlindungan Hukum, Kejadian Ikutan Pasca Imunisasi, Vaksin.}

Abstract-Immunization is a preventive effort that is proven to reduce morbidity, disability, and death. So the government requires the community to get immunization as to the Minister of Health number 42 of 2013 on Immunization Implementation. All immunization rules and procedures have been made by the government on the rights and obligations of the government in organizing immunization. Nevertheless, it has been arranged as well as possible but the problem always exists when there is an Adverse Effect Following Immunization Event (KIPI) which enables Immunization Implementers in performing their duties. Obligations in the implementation of this immunization, of course, can not be avoided by Immunization Implementers although always overshadowed by concerns about the risk of KIPI. Therefore, this study aims to examine the protection and legal policy for Immunization Implementers in performing their duties based on Permenkes number 42 of 2013 on Immunization Implementation in Indonesia. The results of this study indicate that the legal tools prepared in the implementation of immunization are sufficient, but the lack of legal understanding often raises concerns will occur KIPI, therefore in the implementation of immunization should the implementers understand the risk of errors and omissions work, and it requires the socialization made by government regulation on regulations relating to the implementation of immunization in Indonesia.

Keywords: Legal Protection, Post Immunization Events, Vaccines. 


\section{A. PENDAHULUAN}

Kejadian Ikutan Paska Imunisasi (KIPI) yang paling serius terjadi pada anak adalah reaksi anafilaksis. Angka kejadian reaksi anafilaktoid diperkirakan 2 dalam 100.000 dosis DPT, tetapi yang benar-benar reaksi anafilaksis hanya 1-3 kasus di antara 1 juta dosis. Anak yang lebih besar dan orang dewasa lebih banyak mengalami sinkope, segera atau lambat. Episode hipotonik/hiporesponsif juga tidak jarang terjadi, secara umum dapat terjadi 4-24 jam setelah imunisasi (Kassianos, 1996:3).

Dalam kegiatan imunisasi terdapat beberapa kejadian ikutan (side effect) yang dikenal dengan Kejadian Ikutan Pasca Imunisasi (KIPI). KIPI merupakan kejadian medik yang berhubungan dengan pelaksanaan imunisasi, baik berupa efek vaksin ataupun efek samping toksisitas, reaksi sensitivitas, efek farmakologis atau kesalahan program (Departemen Kesehatan RI, 2002).

KIPI adalah kasus merugikan pasien dan menjadi masalah pada profesi tenaga kesehatan yang menjalankan tugas dalam memberikan pelayanan imunisasi. Kasus KIPI di Kabupaten Sukabumi tahun 2013 ada 7 kasus, tahun 2014 ada 8 kasus, dan tahun 2015 ada 6 kasus dan ini sering dihubungkan dengan anggapan kegiatan malpraktik oleh pihak yang dirugikan (Sitem Informasi Kesehatan, 2015).

Dalam beberapa tahun terakhir ini sering timbul gugatan dari pasien yang merasa dirugikan, untuk menuntut ganti rugi akibat kesalahan atau kelalaian yang di lakukan oleh dokter atau tenaga kesehatan dalam melaksanakan pekerjaannya. Berbagai kasus telah di sidangkan di pengadilan dan mendapat sorotan dari profesi kalangan kesehatan dan profesi hukum, walaupun kasus ini belum menyangkut kasus KIPI (Ranuh, 2011).

Munculnya kasus-kasus tersebut di atas merupakan indikasi bahwa kesadaran hukum masyarakat semakin meningkat. Sehingga masyarakat menuntut hak atas kerugian karena ada anggapan kesalahan manusia (human error) dalam menjalankan tugasnya. Biasanya pasien KIPI ini didukung oleh lebaga tertentu (Lembaga 
Hukum, LSM atau institusi) yang merasa tahu akan adanya tidakan malpraktek. Sementara petugas imunisasi belum banyak yang mengetaui tentang hak dan kuajibannya secara hukum, oleh karena itu petugas kesehatan merasa takut akan ancaman pidana dan ancaman ganti rugi yang akan terbeban padanya.

Berdasarkan Peraturan Menteri Kesehatan Republik nomor 42 tahun 2013 tentang Penyelenggaraan Imunisasi bab $\mathrm{V}$ tentang Pemantauan dan Penanggulangan KIPI sudah menjelaskan bahwa setiap pelaksana imunisasi yang harus melaksanakan tugas dan menjalankan tugasnya berdasar Petunjuk Pelaksanaan (Juklak) yang berlaku, kasus KIPI akan ditangani oleh Kelompok Kerja (Pokja) KIPI kabupaten/kota dan dilaporkan ke Komda KIPI provinsi untuk dapat menjelaskan tentang kasus dugaan KIPI tersebut. Jadi tidak beralasan petugas imunisasi merasa khawatir dalam menjalankan tugasnya karena sudah dilindungi undang-undang (Gunawan, 2000).

Juklak adalah dasar hukum untuk petugas imunisasi dalam menjalankan tugas. Permasalahan yang sering terjadi bahwa para petugas imunisasi banyak yang tidak membuat catatan visum disetiap pekerjaan mereka. Makanya banyak tuntutan hukum dianggap kesalahan dalam menjalankan Juklak tersebut (Proverawati, dan Andhini, 2010).

Hal ini menjadi polemik pelaksana imunisasi dalam menjalankan tugasnya. Walau sudah menjalankan Juklak sesempurna apapun tetapi resiko KIPI ada kemungkinan terjadi pada pasien yang mereka tangani. Mereka tetap harus menjalankan tugas karena imunisasi adalah program wajib. Kekhawatiran pelaksana imunisasi seharusnya menjadi keperdulian pemerintah yang tidak boleh dipandang remeh, seharusnya bukti pelaksanaan Juklak punya kekuatan hukum sehingga para pelaksana imunisasi dapat menjalankan tugas dengan tenang.

Permasalahan dalam penelitian adalah bagaimana perlindungan hukum bagi Pelaksana Imunisasi berdasarklan undang-undang nomor. 42 tahun 2013 tentang imunisasi, jika terjadi KIPI yang merugikan pasien, 
Ahmad Juanda, Perlindungan Hukum Pelaksana Imunisasi Dalam Kejadian...

dan tanggungjawab hukum Pelaksana Imunisasi ketika terjadi kerugian bagi pasien pada Kejadian Ikutan Paska Imunisasi (KIPI).

\section{B. HASIL DAN PEMBAHASAN}

1. Perlindungan

Hukum

Pelaksana Imunisasi Dalam Kejadian Ikutan Pasca Imunisasi (KIPI)

Pada pelaksanaan imunisasi hal yang sangat dikhawatirkan oleh pelaksana imunisasi adalah bila terjadi Kejadian Ikutan Paska Imunisasi (KIPI) pada pasien yang berujung pada penuntutan hukum atau tuntutan ganti rugi yang nilainya cukup fantasis yaitu puluhan sampai ratusan juta dan pelaksana imunisasi hanya bisa pasrah kepada Dinas Kesehatan tentang apa yang akan terjadi. Biasanya pihak Dinas Kesehatan dan keluarga pasien melakukan negosiasi "damai” supaya keluarga pasien tidak melanjutkan ke pengadilan. Terpaksa pelaksana imunisasi harus ikut membantu mengeluarkan uang "damai" tersebut.

Sebenarnya pasien Kejadian Ikutan Paska Imunisasi (KIPI) ini masih dalan kategori dugaan karena di dalan Permenkes nomor 42 tahun 2013 tentang penyelenggaran imunisasi pada Bab V menjelaskan bahwa laporan dugaan Kejadian Ikutan Paska Imunisasi (KIPI) ditangani oleh Komnas PP KIPI Pusat, Komda KIPI Provinsi dan Pokja KIPI Kabupaten/Kota yang secara berjenjang akan menginvestigasi apakah Kejadian Ikutan Paska Imunisasi (KIPI) ini akibat imunisasi atau karena penyebab yang lain.

Seharusnya Pelaksana imunisasi tidak perlu khawatir berlebihan karena hasil investigasi Komda KIPI ini akan menjelaskan apakah dugaan Kejadian Ikutan Paska Imunisasi (KIPI) ini terbukti karena akibat kesalahan atau kelalaian pelaksana imunisasi atau faktor lain secara medis. Kalau hasil investigasi tersebut menyatakan bahwa kasus merupakan akibat faktor medis yang lain dan bukan karena kausalitas imunisasi dan pihak pasien tetap tidak bisa terima dengan hasil investigasi Komda KIPI itu hak pasien untuk meminta pengadilan dalam memutuskan perkara ini. 
Pelaksana Imunisasi sudah tentang Pelaksana imunisasi sudah punya bukti kuat secara hukum karena hasil investigasi yang dilakukan oleh Komda KIPI dan dilaporkan ke Menteri Kesehatan melalui Komnas KIPI ini dilakukan oleh para profesional medis yang sudah bersetifikasi yang dilindungi undang-undang yang belaku. Jadi selama di dalam laporan hasil investigasi tidak ada yang ditutuptutupi atau kebohongan dalam pelaporan investigasi tersebut maka kemungkinan besar Pelaksana Imunisasi akan menang dalam perkara ini, karena penyelidikan ulang dalam dugaan Kejadian Ikutan Paska Imunisasi (KIPI) ini akan juga dilakukan oleh tenaga profesional medis yang berbeda sebagai pembanding dan akan menggunakan standar Petunjuk Pelaksanaan (Juklak) dan Petunjuk Teknis (Juknis) yang sama dan sudah diatur dalam perundang-undangan. Jadi kemungkinan akan ada perbedaan hasil penyelidikan yang dilakukan oleh pengadilan akan sangat tidak bermakna.

Permasalahan yang akan muncul adalah bukti-bukti hukum menjalankan tugasnya sesuai Juklak dan Juknis dalam pelaksanaan imunisasi, misalnya waktu penerimaan vaksin dari pengelola penyimpan vaksin kepada pelaksana imunisasi dalam keadaan baik (sesaui aturan yang berlaku), pengendalian rantai dingin (cold chain) dari gudang penyimpan vaksin sampai ke tempat pelaksanaan imunisasi apakah sudah sesuai prosedur dan saat pemberian vaksin dalam pelaksanaan imunisasi pelaksana imunisasi sudah sesuai aturan yang sudah ditentukan. Sebagai contoh apakah pasien dalam keadaan yang sudah sesuai aturan untuk diberikan vaksin dan lain sebagainya. Pelaksana imunisasi bisa saja mengatakan bahwa semua yang dilakukan sudah sesuai aturan dalam Juklak dan Juknis yang berlaku tetapi jawaban kejujuran dapat dijadikan bukti sah dalam pengadilan.

Profesionalisme dalam pekerjaan sebagai pelaksana imunisasi ini sudah diakui secara hukum, tetapi saat terjadi kasus permasalahan yang di luar dari dugaan pelaksana imunisasi ini harus punya bukti hukum bahwa semua 
yang dilakukan seaui aturan dalam imunisasi. Karena dalam pengadilan tidak dapat mempercayai begitu saja oleh jawaban tersangka dan para saksi, harus ada bukti hukum yang dapat meyakinkan pengadilan. Kalau bukti autetentik tidak dapat dipercaya oleh pengadilan maka pelaksana imunisasi dalam keadaan lemah yang kemungkinan akan terancam kesalahan dalam pelaksanaan imunisasi.

Sebagai contoh saat pelaksana imunisasi mengambil vaksin dari pengelola penyimpan vaksin dan pelaksana imunisasi menerima vaksin dalam keadaan baik (suhu pendingin sudah sesuai dan kemasan dalam keadaan baik), secara profesional pelaksana imunisasi sudah membawa vaksin yang pantas untuk diberikan kepada pasien. Tetapi bukti apa yang harus dibuat dan siapa saja yang berkewajiban dalam memverifikasi bahwa transaksi pengambilan vaksin ini sudah sesuai dengan aturan yang sudah ditentukan. Hal inilah yang harus dikaji ulang supaya pelaksana imunisasi punya bukti-bukti hukum bahwa vaksin yang digunakan dalam pelaksanaan imunisasi dalam keadaan benar.

Peralatan rantai dingin untuk membawa vaksin ke tempat pelaksanaan imunisasi juga perlu ditegaskan secara bukti hukum yaitu harus ada yang memveryfikasi bahwa suhu dan kemasan vaksin dalam keadaan baik oleh pihak-pihak terkait misalnya Ketua RT atau Kader dalain sebagainya sehingga vaksin yang dibawa di tempat pelaksanaan imunisasi dapat dipercaya secara hukum bahwa vaksin dalam keadaan baik.

Pada pelaksanaan imunisasi juga harus ada yang memverifikasi tentang tatacara pemberian vaksin bahkan kalau perlu ditunjukkan aturan-aturan pemberian vaksin dan dijelaskan tentang efek samping yang kemungkinan terjadi kepada semua pasien yang akan diimunisasi dan diberikan informed consent bahwa semua yang dilakukan dalam pemberian vaksin sesaui aturan yang sudah ditentukan dan ada bukti serta saksi-saksi yang sah secara hukum.

Kalau bukti-bukti kebenaran dalam tatacara pemberian vaksin sudah dibuat secara autentik sah 
Ahmad Juanda, Perlindungan Hukum Pelaksana Imunisasi Dalam Kejadian...

secara hukum oleh para pelaksana imunisasi maka tidak perlu ada kekhawatiran pelaksana imunisasi dalam menjalankan tugasnya. Karena bila kasus Kejadian Ikutan Paska Imunisasi (KIPI) itu benar-benar terjadi kemungkinan besar bukan kesalahan atau kelalaian pelaksana imunisasi tetapi karena faktor lain. Vaksin walaupun sudah dinyatakan aman dan mempunyai manfaat baik untuk mencegah kesakitan, kecacatan dan kematian pada masyarakat tetapi tetap mempunyai efek yang buruk yang sudah dibuktikan dalam penelitian produsennya yaitu 2/100.000 kejadian. Jadi jika semua penyelenggaran imunisasi sudah dikendalikan dengan baik kemungkinan terjadi Kejadian Ikutan Paska Imunisasi (KIPI) walaupun sangat kecil.

Maka dari itu Pelaksana imunisasi wajib memastikan bahwa vaksin yang diambil dari gudang penyimpanan vaksin harus pada kondisi sesuai standar dan tercatat dalam buku visum yang diveryfikasi oleh yang berwenang. Sebelum Pelaksana Imunisasi memberikan vaksin kepada pasien seharusnya ditunjukkan bahwa vaksin dalam keadaan baik sesuai standar yang sudah ditetapkan oleh Pemerintah. Jadi bila Kejadian Ikutan Paska Imunisasi (KIPI) terjadi maka Pelaksana Imunisasi punya bukti yang kuat bahwa kesalahan bukan terjadi pada Pelaksana Imunisasi tetapi mungkin kualitas vaksin sudah tidak baik karena kesalahan atau kelalaian pada pengelola vasin sebelumnya yaitu dari mulai pengadaan sampai ke gudang penyimpanan vaksin di Puskesmas.

\section{Tanggungjawab Hukum}

Pelaksana Imunisasi Dalam Kejadian Ikutan Pasca

\section{Imunisasi (KIPI)}

Pelaksana imunisasi yang melaksanakan pelayanan imunisasi yang tidak sesuai dengan Permenkes nomor 42 tahun 2013 tentang penyelenggaran imunisasi akan mendapat hukuman disiplin yang dijatuhkan terhadap pelaksana imunisasi yang tidak kompeten adalah untuk memperbaiki dan mendidik pelaksana imunisasi yang bersangkutan. Oleh karena itu, jika hukuman disiplin dalam bidang 
pelayanan imunisasi diterapkan bagi tenaga imunisasi, maka dengan sendirinya rasa tanggungjawab yang mendalam akan mendorong mereka untuk melakukan kewajiban profesi dan mematuhi ketentuan-ketentuan hukuman yang telah digariskan.

Pelaksana imunisasi sebagai pemberi pelayanan imunisasi dan pasien sebagai penerima pelayanan imunisasi, memiliki tanggung gugat hukum, bertitik tolak dari transaksi terapeutik ini, terjadi gugatan untuk meminta pertanggungjawaban tenaga kesehatan. Gugatan tersebut bersumber pada dua dasar hukum, yaitu: pertama, berdasarkan pada wanprestasi (Contractual liability) sebagaimana diatur dalam Pasal 1239 KUHPerdata. Kedua, berdasarkan perbuatan melanggar hukum (onrechmatigedaad) sesuai dengan ketentuan Pasal 1365 KUHPerdata.

Adanya gugatan pasien terhadap tenaga kesehatan adalah dalam hal adanya wanprestasi dalam pelaksana imunisasi. Wanprestasi dalam pelayanan imunisasi, timbul karena tindakan seorang pelaksana imunisasi berupa pemberian imunisasi yang tidak patut sesuai dengan apa yang diperjanjikan. Pelayanan yang tidak patut ini dapat berupa tindakan kekurang hati-hatian, atau akibat kelalaian dari pelaksana imunisasi yang bersangkutan sehingga menyalahi tujuan terapeutik.

Dalam gugatan atas dasar wanprestasi, ketiga unsur tersebut harus dibuktikan terlebih dahulu adanya kontrak terapeutik antara pasien dengan pelaksana imunisasi. Pembuktian tentang adanya kontrak terapeutik dapat dilakukan pasien dengan mengajukan rekam medik atau dengan persetujuan tindakan medik yang diberikan oleh pasien. Bahkan dalam kontrak terapeutik adanya kartu berobat atau dengan kedatangan pasien menenmui pelaksana imunisasi untuk meminta pertolongannya, dapat dianggap telah terjadi perjanjian terapeutik, ini merupakan sebuah informed consent secara implisit dan memang sebaiknya sebelum melaksanakan imunisasi diberikan informed consent yang ditandatangani oleh pasien atau orang tua pasien bahwa semua sudah dijelaskan sesuai aturan imunisasi yang berlaku. Sedangkan untuk unsur yang kedua, harus dibuktikan dengan 
adanya kesalahan dan atau kelalaian pelaksana imunisasi. Untuk membuktikan hal ini pasien harus mengajukan fakta bahwa pelaksana imunisasi yang memberikan imunisasi, tidak melakukan apa yang disanggupi akan dilakukan dalam kontrak terapeutik, atau pelaksana imunisasi melakukan apa yang diperjanjikan akan tetapi terlambat, atau pelaksana imunisasi yang bersangkutan melakukannya tidak sesuai dengan yang diperjanjikan, atau pelaksana imunisasi melakukan sesuatu yang menurut pernanjian tidak boleh dilakukan. Agar unsur yang ketiga dapat terpenuhi, semua tindakan pelaksana imunisasi seperti di atas harus mempunyai hubungan kasual dengan kerugian yang diderita pasien.

Jika timbul perselisihan atau pertentangan antara pasien dengan pelaksana imunisasi tentang pemberian persetujuan pada suatu tindakan imunisasi, di mana pasien mengatakan tidak pernah memberikan persetujuan, sedangkan pelaksana imunisasi sebaliknya menyatakan sudah mendapat persetujuan untuk melakukan tindakan imunisasi.
Dalam hal terjadinya kasus seperti ini, dimana posisi pembuktian dari kedua pihak sangat sulit, hakim akam mencoba menghindari perintah pembebanan pembuktian kepada salah satu pihak. Hakim dalam hal ini berpaya mencari imformasi sebanyak mungkin dari pasien dan dari suatu penjelasan di persidangan. Apabila diperlukan perintah pembebanan pembuktian, maka dalam mempertimbangkannya agar supaya kedudukan pelaksana imunisasi lebih diuntungkan daripada pasien, karena pelaksana imunisasi telah membuat catatan-catatan tertulis tentang keadaan pasien (medical record), kecuali kalau ada kesan bahwa catatan itu tidak beres. Hakim tidak akan memerintahkan pembagian beben pembuktian secara umum kepada salah satu pihak. Hakim hanya akan menggantungkan beban pembuktian secara umum kepada salah satu pihak, hakim hanya akan menggantungkan beban pembuktian pada keadaan konkrit.

Pembuktian adanya hubungan kausal antara perbuatan dengan kerugian menurut ajaran teori conditio sine quo non tidak dapat 
diterapkan dengan sempurna, tetapi hanya disimpulkan sebagai the must possible cause yaitu, sebab yang paling mungkin. Sebaliknya, dalam adequate theorie yang bertujuan memberi pembatasan pada pertanggungjawaban. Dalam yurisprudensi tersebut, yang menjadi permasalahan adalah bagaimana kriteria secara konkrit mengenai istilah "Akal yang sehat dapat diharapkan" atau "menurut pengalaman yang dapat diharapkan”, atau "sepatutnya dapat diduga semula".

Dilihat dari hukum pidana, adanya Kejadian Ikutan Pasca Immunisasi (KIPI) harus dilihat dari adanya kesalahan yang dilakukan oleh pelaksana imunisasi yang melakukannya. Hal ini sesuai dengan asas dari hukum pidana bahwa "tiada pidana tanpa kesalahan". Jadi setiap perbuatan kesalahan dari pelaksana imunisasi dalam melakukan immunisasi yang berakibat terjadinya KIPI dapat dimintakan pertanggungjawaban secara pidana atas kesalahannya.

Dalam pelayanan kesehatan timbul pertanyaan, apakah unsur kesalahan tersebut dapat diterapkan terhadap perbuatan yang dilakukan oleh pelaksana imunisasi? Untuk pertanyaan tersebut harus dilihat apakah kesalahan yang dilakukan oleh pelaksana imunisasi, terjadi karena kurangnya pengetahuan, kurangnya pengalaman dan atau kurangnya kehatian-hatian, padahal diketahui bahwa jika dilihat dari segi profesionalisme, pelaksana imunisasi dituntut untuk terus mengembangkan ilmunya. Oleh karena itu unsur-unsur sebagaimana tersebut di atas dapat diterapkan untuk mengukur ada atau tidak adanya kesalahan pelaksana imunisasi dalam menjalani imunisasi.

Dalam kaitannya dengan hal tersebut, Van Bemmelen sebagaimana dikutip Lumintang menyebutkan bahwa yang dimaksud dengan kesalahan dalam bidang hukum pidana adalah Culpa lata atau kesalahan yang sifatnya mencolok (Lumintang, 1984:185).

Oleh karenanya, jika kesalahan seperti itu dihubungkan dengan tindakan yang perlu dilakukan oleh seorang pelaksana imunisasi, dari mereka memiliki cara berpikir yang lebih baik dibanding dengan orang 
Ahmad Juanda, Perlindungan Hukum Pelaksana Imunisasi Dalam Kejadian...

awam, akan tetapi orang kesehatan hal ini dikenal dengan mengharapkan agar mereka berbuat sesuai dengan kepandaian yang dimiliki oleh rekan sejawatnya bila menghadapi masalah yang sama.

C. Berkhouwer. S. dan D. istilah informed consent. Munculnya hak (consent) apabila didahului dengan penjelasan dan pemberitahuan (informed) tentang tindakan medis Vortman menyebutkan bahwa yang akan diambil, mengapa tindakan seorang pelaksana imunisasi dapat dikatakan melakukan kesalahan profesional, apabila dia tidak memeriksa, tidak menilai, tidak berbuat atau tidak meninggalkan hahal yang akan diperiksa, dinilai, diperbuat atau ditinggalkan oleh para pelaksana imunisasi pada umumnya di dalam situasi yang sama (Lumintang, 1984:76).

Dari rumusan ini, terlihat bahwa unsur kehati-hatian dalam melaksanakan profesi pelaksana imunisasi sangat penting. Dalam berbagai yurisprudensi ditentukan bahwa unsur kehati-hatian merupakan dasar untuk menentukan terjadinya kesalahan pelaksana imunisasi. Beberapa yurisprudensi yang memuat unsur kehati-hatian sebagai tolok ukur terjadinya kesalahan pelaksana imunisasi dalam pelayanan imunisasi.

Hak selanjutnya adalah hak persetujuan, dalam ilmu hukum harus diambil dan apa hasilnya maupun kemungkinan efeknya bagi pasien. Semua keterangan yang diberikan harus jelas dan dapat dimengerti oleh pasien, sehingga dengan kesadarannya sendiri pasien akan memberikan persetujuan pemberian imunisasi. Dengan demikian "persetujuan" merupakan dasar bagi pembenaran dilakukannya salah satu tindakan terapeutik tertentu, persetujuan baik yang diberikan secara tertulis maupun diam-diam mempunyai arti dalam pandangan hukum.

Dalam kaitannya dengan ganti rugi sebagaimana diatur dalam Pasal 55 Undang-Undang Nomor 36 Tahun 2009, persetujuan/rekam medik menjadi sangat penting. Hal ini disebabkan gugatan ganti rugi langsung tanpa melalui prosedur pidana menghadapi banyak kendala, seperti kesulitan memperoleh buktibukti baik oleh pasien maupun oleh 
keluarganya. Sedangkan melalui kesehatan merupakan bagian dari perkara pidana untuk membuktikan profesionalime, disamping adanya culpa lata bukan merupakan memberikan refleksi mengenai pekerjaan yang mudah bagi penuntut kualitas vaksin, rekam medik yang umum. Dalam kondisi seperti ini, tertulis itu merupakan kunci dalam sesuai dengan hukum pembuktian dalam perkara pidana Pasal 184 KUHP tentang Alat Bukti, maka persetujuan/rekam medik sangat menentukan, karena dari rekam medik dan atau consent yang diajukan sebagai alat bukti dapat diketahui perihal imunisasi yang dilakukan terhadap pasien. Apakah sudah sesuai dengan standar profesi atau belum? Dari consent dapat pula diketahui apakah dalam melakukan pemeriksaan, pelaksana imunisasi sudah bekerja sesuai dengan apa yang disetujui pasien. Sehingga dengan demikian, hakim dapat menentukan apakah pelaksana imunisasi dapat dipersalahkan atau tidak. Sejalan hal terlebih duluan itu menyebutkan: salah satu jalan reliable untuk meyakinkan bahwa setiap orang memperhatikan apa yang diinformasikan secara lengkap dan akurat mengenai pelayanan kesehatan ini ialah dengan telah membuat rekaman tertulis. Suatu rekam medik suatu proses peradilan baik perdata maupun pidana. Semua yang dibicarakan di atas, menyangkut tentang standar pelayanan imunisasi dan standar profesi yang bertujuan untuk menentukan ada atau tidaknya kesalahan pelaksana imunisasi.

\section{SIMPULAN}

1. Perlindungan hukum bagi Pelaksana imunisasi di Kabupaten Sukabumi yang diatur dalam Permenkes nomor 42 tahun 2013 tentang Penyelenggaran Imunisasi. Ketidakpahaman tentang perundang-undangan dan peraturan-peraturan pelaksanaan imunisasi dan pengimplementasian hukum dari perundang-undangan dan peraturan-peraturan imunisasi inilah yang membuat pelaksana imunisasi merasa tidak terlindungi hukum maka dalam Kejadian Ikutan Paska 
Ahmad Juanda, Perlindungan Hukum Pelaksana Imunisasi Dalam Kejadian...

Imunisasi (KIPI) ini pelaksana imunisasi harus terpaksa dirugikan dengan adanya negosiasi "damai" yang harus ikut memberikan material dalam "perdamain" tersebut. Sehingga walau tidak terjerat dalam tuntutan hukum tetapi tetap merasa disalahkan karena adanya pembayan kompensasi "damai" yang seharusnya tidak harus mereka tanggung kalau pelaksana imunisasi merasa punya bukti kuat bahwa kasus yang terjadi bukan karena keslahan atau kelalaian pelaksana imunisasi.

2. Tanggungjawab hukum bagi pelaksana imunisasi yang menyebabkan kerugian pada pasien akan mendapat pengadilan sesuai tingkat kesalahan yang diperbuat. Pasien sebagai penerima jasa dilindungi oleh Undang-undang nomor 8 tahun 1999 pelindungan konsumen. Oleh karena ada tiga hal yang akan menjerat pelaksana imunisasi jika melakukan kesalahan atau kelalaian berdasarkan tingkatan hukuman yaitu hukuman administratif, hukuman perdata dan hukuman pidana. Hukuman ini akan ditetapkan dalam proses pengadilan dengan penyelidikan berdasarkan buktibukti di kedua belah pihak yaitu pemberi jasa (pelaksana imunisasi) dan penerima jasa (pasien) yang dirugikan.

\section{SARAN}

1. Seharusnya Dinas Kesehatan Kabupaten Sukabumi menyebarluaskan kepada seluruh Puskesmas untuk memahami Permenkes nomor 42 tahun 2013 tentang Penyelenggaraan Imunisasi sehingga semua pelaksana imunisasi dapat melaksanakan imunisasi sesuai peraturan yang berlaku.

2. Seharusnya Dinas Kesehatan Kabupaten Sukabumi menghimbau semua pelaksana imunisasi membuat catatancatatan yang diverifikasi oleh pejabat yang berwenang dan selalu memberikan informed consent sehingga bila terjadi 
Ahmad Juanda, Perlindungan Hukum Pelaksana Imunisasi Dalam Kejadian...

Kejadian Ikutan Paska

Imunisasi (KIPI) pelaksana

imunisasi mempunyai bukti-

bukti kuat secara hukum dapat

terhidar dari tuntutan hukum.

3. Seharusnya Dinas Kesehatan

Kabupaten Sukabumi

memberikan sosialisasi tentang

Undang-undang nomor 8 tahun

1999 tentang Perlindungan

Konsumen supaya Pelaksana

Imunisasi lebih teliti dan hati-

hati dalam menjalankan Juklak

dan Juknis tentang pelaksanaan

imunisasi secara benar.

\section{DAFTAR PUSTAKA}

Departemen Kesehatan RI, Pedoman Operasional Pelayanan

Imunisasi, Jakarta, 2002.

Gunawan, dkk, Kejadian Ikutan Pasca Imunisasi Antigen Vi Polisakarida Kapsuler, Ilmu Kesehatan Anak, Salemba Medika, Jakarta, 2000.

Kassianos G.C., Immunization Childhood and Trame Health, Edisi ketiga, Penyunting,
Blackwell Science, London, 1996.

Lumintang, Dasar-dasar Hukum Pidana Indonesia, Sinar Baru, Bandung, 1984.

Proverawati, A., dan Andhini, D.S., Imunisasi dan Vaksinasi, Numed, Yogyakarta, 2010.

Ranuh, dkk, Buku Imunisasi di Indonesia, Satgas Imunisasi IDAI, Jakarta, 2011.

Sitem Informasi Kesehatan, Profil Dinas Kesehatan Kabupaten Sukabumi Tahun 2015. 